\title{
Cinobufagin Suppresses the Characteristics of Osteosarcoma Cancer Cells by Inhibiting the IL-6-OPN-STAT3 Pathway [Retraction]
}

\author{
Zhang C, Ma K, Li WY. Drug Des Devel Ther. \\ 2019;13:4075-4090.
}

The Editor and Publisher of Drug Design, Development and Therapy wish to retract the published article. The authors advised that errors were made in Figure 3A and they could not provide satisfactory original data that would validate the findings of their study. The Editor advised for the article to be retracted.
Our decision-making was informed by our policy on publishing ethics and integrity and the COPE guidelines on retraction.

The retracted article will remain online to maintain the scholarly record, but it will be digitally watermarked on each page as "Retracted".

\section{Publish your work in this journal}

Drug Design, Development and Therapy is an international, peerreviewed open-access journal that spans the spectrum of drug design and development through to clinical applications. Clinical outcomes, patient safety, and programs for the development and effective, safe, and sustained use of medicines are a feature of the journal, which has also been accepted for indexing on PubMed Central. The manuscript management system is completely online and includes a very quick and fair peer-review system, which is all easy to use. Visit http://www. dovepress.com/testimonials.php to read real quotes from published authors. 